\title{
Green Technological Development and Deployment in the Association of Southeast Asian Economies (ASEAN)—At Crossroads or Roundabout?
}

\author{
Rabindra Nepal ${ }^{1, *}$, Han Phoumin ${ }^{2}$ and Abiral Khatri ${ }^{3}(\mathbb{D}$ \\ 1 Faculty of Business and Law, School of Business, University of Wollongong, \\ Wollongong, NSW 2522, Australia \\ 2 Economic Research Institute for ASEAN an East Asia (ERIA), Senayan Jakarta Pusat 10270, Indonesia; \\ han.phoumin@eria.org \\ 3 Department of Business-Society Management, Rotterdam School of Management, \\ Erasmus University Rotterdam, 3062 PA Rotterdam, The Netherlands; khatri@rsm.nl \\ * Correspondence: rnepal@uow.edu.au
}

check for

updates

Citation: Nepal, R.; Phoumin, H.; Khatri, A. Green Technological Development and Deployment in the Association of Southeast Asian Economies (ASEAN)—At Crossroads or Roundabout?. Sustainability 2021, 13, 758. https://doi.org/10.3390/ su13020758

Received: 26 November 2020 Accepted: 12 January 2021 Published: 14 January 2021

Publisher's Note: MDPI stays neutral with regard to jurisdictional clai$\mathrm{ms}$ in published maps and institutional affiliations.

Copyright: (C) 2021 by the authors. Licensee MDPI, Basel, Switzerland. This article is an open access article distributed under the terms and conditions of the Creative Commons Attribution (CC BY) license (https:// creativecommons.org/licenses/by/ $4.0 /)$.

\begin{abstract}
Southeast Asia faces one of the fastest growths in electricity demand in the world, driven by increasing incomes, urbanization and industrialization. Development and deployment of green energy technologies offer a natural conduit to meet the growing electricity needs of the Association of Southeast Asian Economies (ASEAN) region while also serving as a viable strategy to adapt to climate change. The aim of this study is to formulate the policy lessons for the ASEAN economies and governments in facilitating the development and deployment of green technologies and alternatives energy options based on a specific case review of the ASEAN. The ASEAN economic region is prioritizing sustainable economic growth while minimizing the regional impacts of climate change through decarbonization. The study undertakes a case-specific analysis in reviewing green energy deployment in the context of green growth and energy transition using secondary data sources and discusses the current status and future options of renewable energy development in the ASEAN. We find that carbon capture and storage (CCS) technologies will allow the ASEAN to continue to use fossil fuels while achieving sustainable economic growth as coal demand increases in the region. The deployment of CCS technologies will also act as an enabler of hydrogen energy as a green energy solution in the region in the longer term. Boosting public acceptance to nuclear energy, implementing energy efficiency improvement policies and eliminating fossil fuels consumption subsidies are feasible short-term and medium-term policies. Increasing both the public and private sector energy investments and development of CCS technologies in the longer term are necessary complementary policies to maximize the benefits of greater deployment of renewable energy sources in the region and combat climate change.
\end{abstract}

Keywords: green technology; sustainability; climate change; Southeast Asia; energy policy

\section{Introduction}

Sustainable development is about achieving a more sustainable global future so that future societies face fewer challenges arising from resource scarcity and accumulating atmospheric pollutants. Sustainable development is a powerful development concept as it integrates the economic, societal and environmental aspects and the interrelationships among the energy, environment and societal concerns. Developing sustainably ensures that the availability of critical resources such as energy, water and food is available to both present and future generations and emphasizes mitigating the scope of the environmental problems across both geographic and generational boundaries [1]. However, the transition towards sustainability is still at an early stage in developing economic regions while economies around the world have been struggling to balance their economic growth priorities without deteriorating the natural resources. Developing economies and regions 
are expected to be hit hard by climate change due to their more limited adaptation capabilities even though they have produced relatively small amounts of greenhouse gases. The COVID-19 pandemic brings further uncertainty in adapting sustainability reforms to combat climate change given the economic downturn and border closures in many regions affecting resource mobility. Nonetheless, the role and importance of green technology as a climate change adaptation vehicle has always been crucial in providing a new perspective on sustainable development.

Developing economic regions like Southeast Asia currently face paramount challenges as well as opportunities in matching its increasing energy demand due to rising incomes, industrialization and urbanization with sustainable energy supply considering the transition to a lower-carbon economy. Greenhouse gas emissions have been rising rapidly at an average annual rate of $5 \%$ in recent decades among major Southeast Asian economies such as Indonesia, Malaysia Philippines, Thailand and Vietnam [2]. The region is poised to become a net energy importer of fossil fuels such as oil due to growing population, industrialization and urbanization despite the slowdown in economic growth [3]. The total population in the Association of Southeast Asian Economies (ASEAN) region will increase to 715 million by 2025 with the economy growing by more than $5 \%$ per year and therefore explaining a rapid rise in energy demand of at least $4 \%$ annually [4]. The overall growth in energy demand of more than $80 \%$ since 2000 has been met by a doubling in fossil fuel use engendering severe energy security concerns such as rising import dependence and environmental concerns due to an increase in energy-related carbon dioxide $\left(\mathrm{CO}_{2}\right)$ emissions [3]. For instance, the share of this geographic region to global emissions increased to $4 \%$ in 2018 ( $3 \%$ in 2010), while the number of deaths linked to outdoor and household air pollution in Southeast Asia is expected to spike to more than 650,000 a year by 2040, which is an increase from around 450,000 deaths in 2018 [5]. The average temperature in ASEAN is also rising by 0.1 to 0.3 degree Celsius per decade in the last 50 years and is projected to increase by 2-4 degrees Celsius by the end of the 21st century [6]. The electricity demand in the region is growing at an average of $6 \%$ and remains among the fastest in the world, while the region's demand for electricity is projected to double by 2040 [3]. In 2016, the ASEAN economies set a target of $23 \%$ to have its primary energy supply secured from renewable sources by 2025 [4]. However, it is also likely that the overall energy demand will grow by almost $50 \%$, while the power generation will double by 2025 [3]. Some countries in the region will have to at least double their share of renewable energy every year, but a doubling of renewable capacity alone may not be enough to combat climate change. The rising energy demand and related $\mathrm{CO}_{2}$ emissions in the ASEAN, therefore, implicates the heightened need for transitioning towards the development and deployment of greener energy sources as a necessary climate change adaptation strategy in the region.

There is also an ongoing discourse in the ASEAN to devise policy strategies to mitigate and adapt to climate change threats and to balance the trade-offs between economic development and environmental sustainability given the region's heavy reliance on fossil fuels. For instance, the power generation mix of the ASEAN is dominated by fossil fuels, which accounted for almost $80 \%$ in 2017 and are expected to account for $82 \%$ in 2050 in the absence of the region not transitioning to cleaner energy systems [7]. Therefore, the need to develop, deploy and adopt green technologies is imminent for Southeast Asia to address the twin challenges of rising energy demand and increasing emissions in ensuring energy sustainability as well as to mitigate the adverse impacts of climate change. The ASEAN economies should increase their share of renewables in the energy mix to $70 \%$ by 2040 to meet their sustainable development goals [8]. However, the progress towards the adoption of green technology such as renewables in Southeast Asia is slower than the anticipated potential across many Southeast Asian economies. Renewable energy only meets around $15 \%$ of demand with the rapid increase in hydropower and modern use of bioenergy in heating and transport [9]. Solar and wind power being the most abundant energy resources in the ASEAN only contribute negligibly to the power mix [7]. The large potential of sustainable use of modern bioenergy remains untapped in the region, although 
electricity from hydropower production has quadrupled since 2000. The Southeast Asian economies are yet to perform globally in renewable energy deployment due to various challenges despite having huge potentials for sustainable energy sources [10]. However, policymakers across Southeast Asia are intensifying their efforts in achieving a common goal of a secure, sustainable and affordable energy sector even though the region is diverse and dynamic [8]. The diversity in energy mix in the region also offers a viable opportunity to accelerate regional physical interconnections of power grids and make greater use of the resource and demand complementariness [11]. Boosting regional power grids in the ASEAN has also been a well-advocated energy policy agenda in the past [12].

The objective of this study is to analyze and review the energy-economy-environment in the ASEAN from an energy sustainability perspective in the context of green energy development and deployment as a powerful climate change adaption policy in the region. In doing so, the study recognizes the inevitable economy-environment tradeoffs between regional economic growth and adverse climate change impacts as a policy tool for policymakers to emphasize. The study assumes that successful energy transition in the ASEAN is only possible by increasing the share of renewables and clean energy and fuels. Therefore, based on our impartial and unbiased analysis using secondary data sources, we propose that the policymakers need to formulate and implement proper policies that are of short-term, medium-term and long-term nature. These policy proposals include scaling of renewable energy deployment, focusing on energy efficiency improvements, discouraging the use of fossil fuels by undertaking energy pricing reforms and embracing hydrogen, carbon capture, utilization and storage technologies. However, significantly accelerating the deployment of renewable energy in the region is challenged by greater levels of investment and financing requirements, which the region needs to overcome alongside managing the energy governance and financial risks.

Our study is also one of the limited studies focused on the deployment and advancement of green energy technologies as a necessary climate change adaption strategy in the context of sustainable development in the ASEAN. The findings of our study are significant to the ASEAN governments and policymakers in crafting a sustainable energy policy through the development and deployment of alternative greener energy options apart from the conventional renewable sources in adapting to adverse impacts of climate change in the region. We undertake a case review of the ASEAN region as a whole as a case-specific analysis based on a secondary data as a suitable approach to examine policy problems that do not easily lend themselves to rigorous quantitative analysis or that cannot be analyzed using econometrics due to the unavailability of disaggregated data [13].

The remainder of the paper is structured as follows. Section 2 is a brief literature review on the deployment of conventional renewable energy in the context of green growth and energy transition and also portrays the current status of conventional renewable energy deployment in the ASEAN. Section 3 discusses green energy innovation and alternative green energy options for the ASEAN in adapting to climate change. The three major proposed policy recommendations are discussed in Section 4 . Section 5 concludes the paper.

\section{Current Status of Renewable Energy Deployment in the ASEAN}

Historically, the development and deployment of conventional green technologies have mostly been carried out in the context of national green growth strategies and energy transition. This is because economies around the world have set challenging targets to reduce greenhouse gas emissions and renewable energy technologies that offer decarbonization pathways and possibilities. Many developing countries have started to adapt strategies related to green growth into their economic development agenda. The gap between the technologies and the capabilities has been addressed on the basis of literature on technology transfer as well as industry insights across the technology lifecycle. Heuristics have been shown to be crucial when it comes to deployment of clean technology from a policymaker perspective, while technology-specific green growth strategies also depend on countries with different income levels as well as their requirements [14]. However, 
several challenges in the energy sector have been identified to meet the renewable energy targets that were set by ASEAN economic community between 2010-2015 [15]. For instance, there has been little progress in terms of regional cooperation in critical areas like physical infrastructure, while various financial constraints, regulatory differences and technological gaps are challenging energy security.

Governments in Indonesia, the Philippines and Singapore have focused on the institutionalization of sustainable energy by aligning with the domestic systems of renewable energy based on an analysis of their sustainable energy policies between 2000 and 2016 [16]. Li et al. [17] in 2020 found a tremendous mismatch between resources and energy demand despite the huge potential for renewable energy in the research about the energy transition in East and Southeast Asia. In another article of 2019 by Lee et al. [18], the impact of fossil fuel aerosols on air quality in Southeast Asia under varying hypothetical fuel consumption scenarios were examined. The results showed that the replacement of coal by natural gas in the power generation and industry sectors would lead to a $25 \%$ reduction in sulphate in the Southeast Asia region. Substituting biofuels by natural gas in the residential sectors would lead to a $42 \%$ reduction in black carbon concentration. The importance of clean air in the Southeast Asian region is also articulated under the findings of the International Energy Agency (IEA) [8] where energy-related air pollution death will rise to 650,000 by 2040 from an estimated 450,000 in 2018. Taghizadeh-Hesary and Rasoulinezhad [19] determined how energy transition patterns depend in 45 Asian economies when classified as per their income levels for the period of 1993-2018 using the generalized method of moments (GMM) estimation approach. The results showed that an increase in population slows the energy transition process across all income levels with economic growth, generating a positive relationship with the energy transition, while $\mathrm{CO}_{2}$ emissions negatively influence energy transition.

There has also been increasing debate about the effects of energy transition in the form of broader global biodiversity threats. Studies have shown that renewable energy facilities can be land-intensive as well as impact conservation areas. Rehbein et al. (2020) [20] assessed that the extent of current and likely future development of renewable energy related to onshore wind, hydropower and solar photo-voltaic generation intervenes with the protected biodiversity areas. It was found that lack of proactive measures like nonremoval of subsidies of fossil fuels and barriers to regional market integration by the ASEAN governments will act as barriers to the region in achieving the ambitious target of $23 \%$ renewables in the primary energy mix by 2025 [9].

The Table 1 below shows that studies focused on the deployment and advancement of green energy technologies in the context of green growth and energy transition are limited for Southeast Asia. Our review study attempts to extend this strand of literature by reviewing the specific case of the ASEAN economic region in search of viable climate change adaptation strategies. Existing studies have mostly focused on the technical and environmental aspects of conventional renewable energy with much disregard for innovative fuels like hydrogen and carbon capture and storage. Our research will contribute to the crafting of sustainable energy policy by the ASEAN governments through the deployment of innovative green technologies in fighting climate change as well as achieving sustainable economic growth in the region.

The ASEAN region is expected to achieve an accelerated economic growth over the next decade and experience 50\% rise in energy demand. Importantly, the region is targeted to source $23 \%$ of its primary energy from renewable sources [4]. The global economic and energy indicators show that ASEAN region is becoming a net importer of fossil fuels given the rapidly growing economies in the region and increasing population size. Oil is likely to continue to dominate the road and transport demand in ASEAN. Similarly, coal demand will increase, driven by strong policy settings by countries to meet the economic growth targets. IEA estimated that more industrial consumers than the power plants drive the demand of natural gas although the increase in imports of oil is making sources such as Liquefied Natural Gas (LNG) less price competitive in the ASEAN. 
Table 1. Literature Summary.

\begin{tabular}{|c|c|c|c|c|}
\hline Year. & Authors & Data & Methodology & Main Findings \\
\hline 2019 & $\begin{array}{l}\text { Jalton Garces } \\
\text { Taguibao }\end{array}$ & 2000-2016 policy documents. & $\begin{array}{c}\text { Examination of policy } \\
\text { discourse of Southeast Asia }\end{array}$ & $\begin{array}{l}\text { Governments in Southeast } \\
\text { Asia tend to reduce the cost } \\
\text { of electricity to make supply } \\
\text { accessible and reliable. }\end{array}$ \\
\hline 2019 & $\begin{array}{c}\text { Hsiang He Lee, } \\
\text { Oussama Iraqui and } \\
\text { Chien Wang }\end{array}$ & $\begin{array}{l}\text { Primary air pollutants and } \\
\text { greenhouse gases from } 2000 \text { to } 2008 \text {. }\end{array}$ & $\begin{array}{l}\text { Weather Research and } \\
\text { Forecasting model coupled } \\
\text { with the modal aerosol } \\
\text { dynamics model for } \\
\text { Europe and the Secondary } \\
\text { Organic Aerosol Model } \\
\text { (SORGAM) }\end{array}$ & $\begin{array}{c}\text { Southeast Asia's sulfate } \\
\text { could be decreased by } 25 \% \text { if } \\
\text { coal could be replaced by } \\
\text { natural gas. }\end{array}$ \\
\hline 2019 & $\begin{array}{l}\text { J. Rehbein, J. Warson, } \\
\text { J. Lane et al. }\end{array}$ & $\begin{array}{c}\text { Key Biodiversity Areas, Protected } \\
\text { Area and Wilderness Area Datasets } \\
\text { on renewable sources. }\end{array}$ & Secondary research & $\begin{array}{l}\text { Negative effect of energy } \\
\text { transition on biodiversity. }\end{array}$ \\
\hline 2020 & $\begin{array}{c}\text { Farhad } \\
\text { Taghizadeh-Hesary } \\
\text { and Ehsan } \\
\text { Rasoulinezhad }\end{array}$ & $\begin{array}{l}\text { Energy transition (renewable energy } \\
\text { consumption/non-renewable energy } \\
\text { consumption) as a dependent } \\
\text { variable, and official exchange rate, } \\
\text { GDP and } \mathrm{CO}_{2} \text { emissions as } \\
\text { independent variables }\end{array}$ & $\begin{array}{l}\text { Panel Generalized Method } \\
\text { of Moments (GMM) } \\
\text { approach }\end{array}$ & $\begin{array}{l}\text { An increase in population } \\
\text { slows the energy transition } \\
\text { process across all economies } \\
\text { at different income levels }\end{array}$ \\
\hline
\end{tabular}

About 120 million people (around 10\% of ASEAN's overall population) still do not have access to electricity in Southeast Asia, and the rural areas face a critical challenge in accessing the power [21]. There are about 45 million people in the region who rely on biomass as a fuel for cooking [8]. There is a tremendous potential for renewable energy, but renewable energy only accounts for $15 \%$ of the energy demand. On one hand, hydropower has increased by four times since 2000 along with the increase in the suse of bioenergy in heating and transport [3]. On the other hand, the share of solar photovoltaics and wind is small, although the costs have been declining in recent years. An efficient market-based energy efficiency framework could strengthen in their deployment but such framework is missing.

Southeast Asia's overall energy demand is also expected to grow by $60 \%$ by 2040 based on a stated policies scenario developed by IEA in 2019. The projection assumes that the size of the economy will double over the period and the majority of the population will be concentrated in the urban areas experiencing an increase of 120 million [22]. A structural economic shift towards less energy-intensive manufacturing and services sectors is expected along with greater energy efficiency improvements, which will lower the rate of energy demand compared to previous decades, although it will represent $12 \%$ of global energy rise by 2040. The oil demand will exceed 9 million barrels per day $(\mathrm{mb} / \mathrm{d})$ by 2040, which is currently at $6.5 \mathrm{mb} /$ day [3].

However, Southeast Asian nations also have a geographic advantage in terms of natural resource endowments to produce renewable energy. For example, Indonesia and the Philippines have substantial geothermal energy potential, while Vietnam, Cambodia, Laos and Myanmar have large-scale hydropower potentials. Similarly, most areas in these countries have at least $12 \mathrm{~h}$ of sunshine on average and are suitable for solar electrification. The global renewable energy generation capacity stood at 2179 GW by the end of 2017, with the hydro sector holding the largest share with an installed capacity of 1271 GW. In the same period, Asia alone accounted for $64 \%$ of the global share in new renewable capacity. The majority of the growth in installed renewable capacities is driven by the new installations of solar and wind energy in the ASEAN (around $85 \%$ of all new renewable capacity installed). Thailand was one of the distinguishable countries in the ASEAN region that had the second-highest share in bioenergy capacity (430 MW). Indonesia topped the 
list in expanding the geothermal energy capacity by $306 \mathrm{MW}$ and is soon approaching a 2 GW total geothermal capacity [23]. Similarly, Malaysia is the third-largest producer of photovoltaic cells in the world while solar is responsible for sourcing the majority $(47 \%$ in 2017) of the grid-connected renewable power generation in Malaysia [24].

Likewise, Laos has around $80 \%$ of its primary energy demand sourced through renewable energy, and the country has realized its potential. Biomass energy, which comes from forestry and agricultural waste, comprises $68 \%$ of its energy and is used for household cooking and small-scale rural production. The remaining $12 \%$ is sourced from the hydropower sector. The commercial methods to utilize biomass in Laos includes direct combustion, gasification, anaerobic digestion and hybrid system [25]. Laos also took advantage of the 300 days of annual sunlight, which enabled its economy to equip 13,000 rural homes with solar panels. In Indonesia, the government has taken the initiative to build a large-scale floating power plant, which has opened doors for 60 other reservoirs across the country [26]. The country has huge potential for wind, and a 100-hectare wind farm was opened in South Sulawesi that has a capacity to power around 70,000 households [27].

The Philippines has the largest potential for wind energy in Southeast Asia, although a significant proportion of the population does not have access to electricity, compelling them to use alternate methods for cooking and lighting. Green start-ups have played a major role in the Philippines by benefitting from the natural energy resource endowments. A Filipino startup named Sustainable Alternative Lighting came up with a saltwater solution-powered lamp product that retains power for up to eight hours. Furthermore, the disposable component of the lamp lasts for 6 months and is also not expensive to replace. Around 51\% people use firewood or charcoal in the Philippines [28].

Figure 1 shows that the region's energy demand is expected to rise to $60 \%$ by 2040 . This expected rise in energy demand is far lower compared with the energy demand of the previous decades. The renewable share in power generation is expected to rise from $24 \%$ in 2020 to $30 \%$ by 2040 . However, the expected rate of progress in renewable energy is still short of levels reached by other emerging economies such as China and India under the stated policies scenario. The hydropower sector that accounts almost $80 \%$ of the renewable share is the cornerstone of ASEAN's energy portfolio and the rise of wind and solar energy as well as biofuels, and bioenergy from waste products is likely to deliver promising growth. Furthermore, innovation in hydrogen carbon technologies could positively change the energy landscape of ASEAN [7].

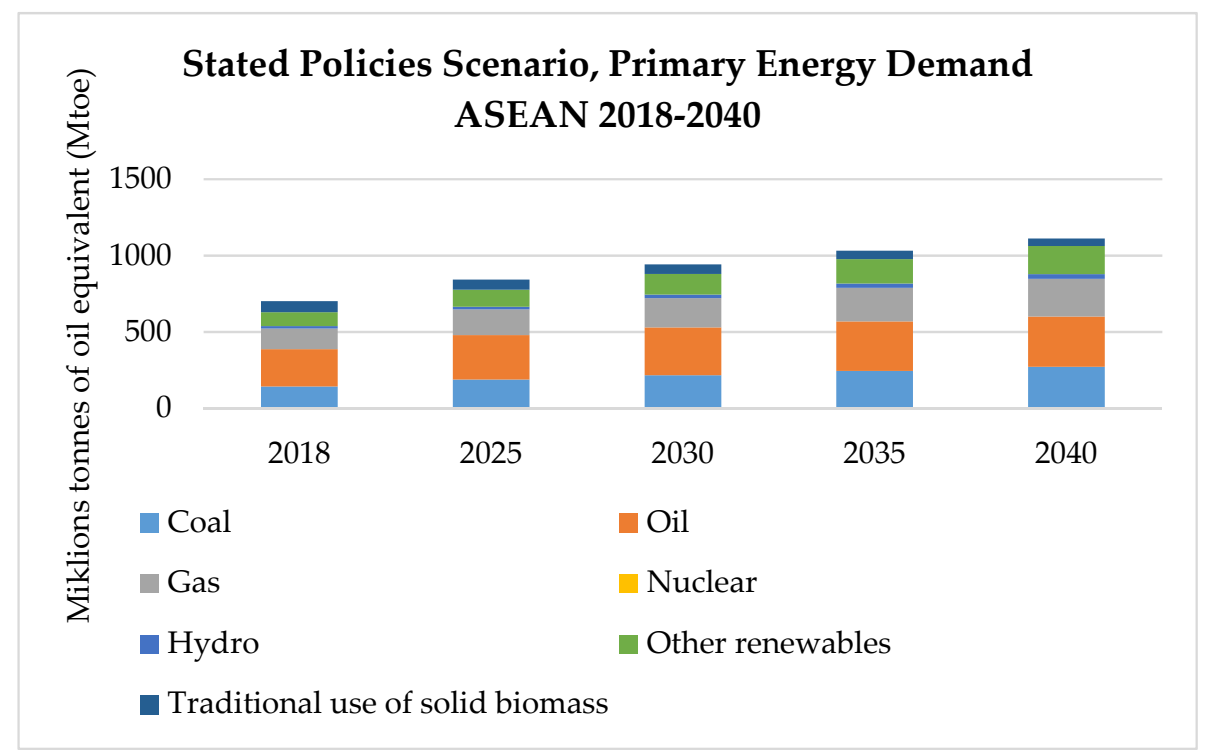

Figure 1. Primary Energy Demand in the Association of Southeast Asian Economies (ASEAN) (2018-2040). Source: Adapted from IEA [3]. 
Figure 2 portrays the economic and energy outlook of the Southeast Asian region in the global context. While the region is experiencing one of the highest increases in electricity demand at an average of $6 \%$ per year, the numbers of power systems in the region face major financial backlash. The use of overall energy demand cannot be undermined either, as the overall energy demand has grown by more than $80 \%$, with fossil fuel use doubling. The renewable energy capacity potential in Southeast Asia is significant enough and is continuously growing as observed in Figure 2. Nevertheless, only 15\% of the region's energy demand is met at present from renewable energy sources, although the scope for renewable energy in the region is tremendous. The falling costs of solar photovoltaics and wind could be encouraging news for supporting their deployment, especially for the small economies in the region such as Myanmar, Cambodia, Vietnam and Laos.

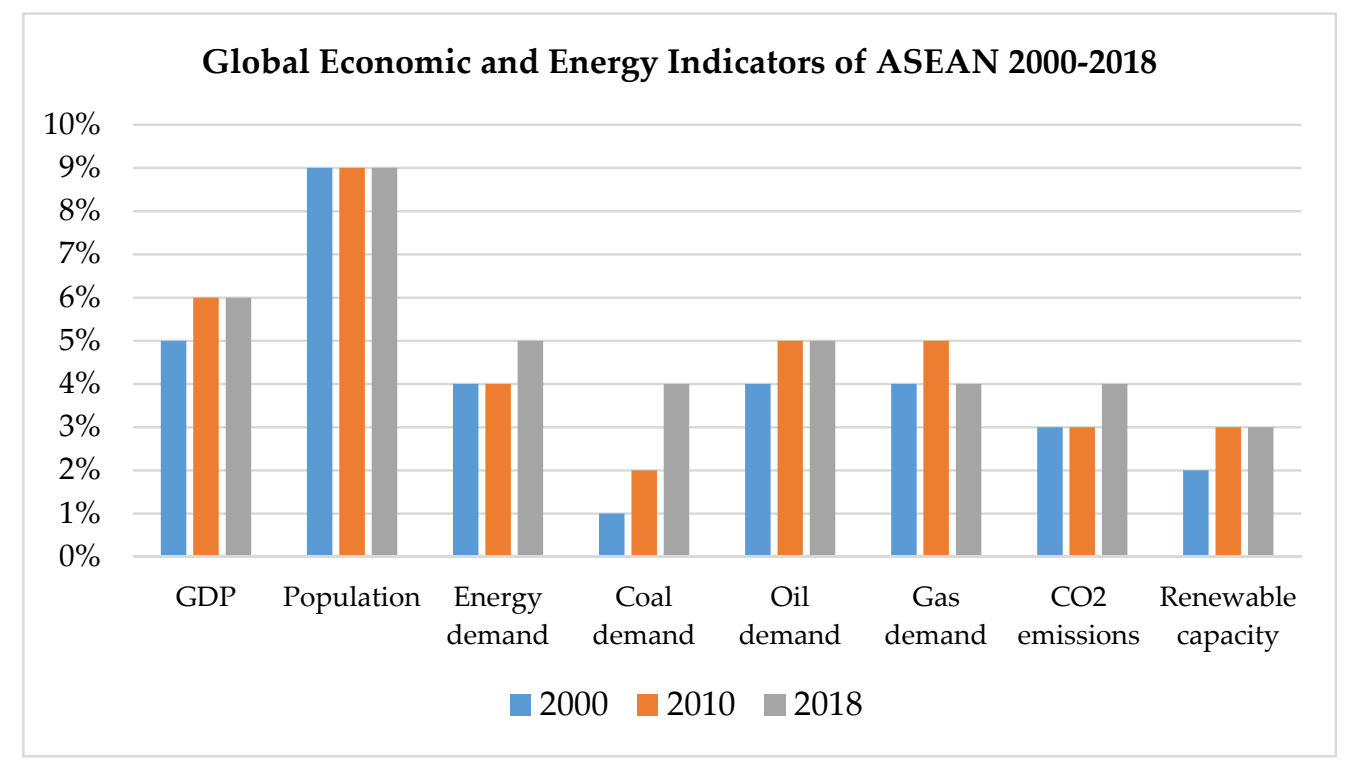

Figure 2. Economic and Energy Indicators in the ASEAN (2000-2018). Source: Adapted from IEA [3].

Hydropower output has also quadrupled in Southeast Asia since 2000 [3]. The costs for solar photovoltaics (PV) have been falling over time, but the share in total energy remains small. IEA [3] data also show that there has been a shift towards low energy-intensive manufacturing and services given the projected rate of energy demand growth is lower than the past two decades, which holds $12 \%$ share of the projected rise in global energy use to 2040. Figure 3 below also shows that space cooling is set to drive the growth in household electricity demand in the ASEAN by 2040.

Achieving a clean energy future in the ASEAN requires electrifying the transport sectors by deploying green technologies like electric vehicles. However, the congested roads and lack of proper infrastructure make it difficult to scale up and replace oil consumption. The rise of middle income and the increasing demand for household space cooling has increased the energy use for air conditioners in ASEAN by 7.5 times in the past 30 years. Indonesia, which is the most populated country in ASEAN, only has about $10 \%$ of its households with air conditioning, and less than $20 \%$ of households in the whole ASEAN region have air conditioning. However, these numbers are likely to keep growing, and an additional 200GW of capacity needs to be added by ASEAN countries by 2040, which will increase demand by $30 \%$ [29]. There are opportunities, at the same time, to increase energy efficiency policies, which could in turn enhance efforts to improve the building and equipment efficiency. Policymakers must understand that hydrogen is one of many alternatives available to fossil fuels, given the high significance in energy storage, longerdistance driving and faster filling [7]. 


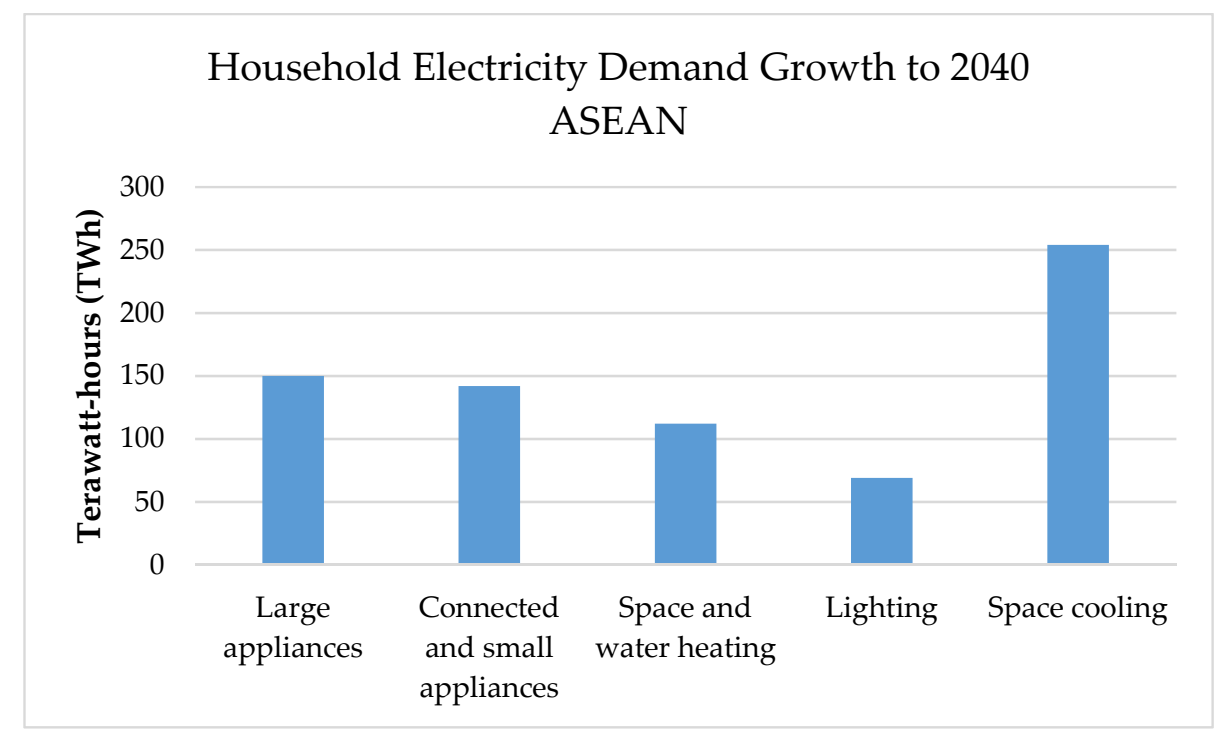

Figure 3. Household electricity demand growth in the ASEAN (by appliance source). Source: Adapted from IEA [3].

\section{Green Innovation and Alternative Energy Options in the ASEAN}

Meeting the energy-related sustainable development goals (SDGs) in the ASEAN requires deploying multiple technologies and policy approaches in the energy sector. As there are no silver bullets, international experiences of energy transitions can offer valuable guidance and insights in the development and deployment of green energy technologies in the ASEAN, considering that fossil fuels have dominated the planet for centuries and will continue to do so. While the removal of carbon from the atmosphere is urgent, innovative energy solutions should be adapted considering the environmental, technological and economical aspects. Policymakers need to have a practical orientation towards the frameworks that are being developed internationally towards the deployment of green technologies so that the energy transition becomes smooth. A report by IRENA showed that Southeast Asia has the highest share of jobs in renewable energy (83\%), whereas it is the lowest in terms of energy efficiency jobs (only 7\%) [30]. Renewable energy technology varies significantly across the member states in ASEAN, although there has been some significant progress made in renewable energy development.

\subsection{Nuclear Energy}

Nuclear power systems are comparatively clean and a reliable source of energy with the potential to contribute towards hydrogen economy. Many countries in Southeast Asia have also expressed increasing interest in nuclear energy given the economic benefit as well as low-carbon emissions for electricity supply [31]. In addition to renewables, the technological advancement of nuclear reactors is already considered to have the possibilities of transforming the clean energy sector in Southeast Asia [32]. The substantial possibility for cost-effective, efficient and large-scale hydrogen production utilizing heat derived from nuclear power station already exists. For example, the US Department of Energy introduced the Advanced High-Temperature Reactor (AHTR) technology build for hydrogen production with high-temperature water electrolysis or thermochemical cycles [33]. Several studies on the thermochemical cycle have delivered thermal-to-hydrogen energy efficiencies of, e.g., $50 \%$ for the adiabatic UT-3 cycle and $52 \%$ for the sulphur-iodine cycle [34]. Hence, economically sound and technologically superior hydrogen production capacities could be sourced from nuclear energy. Nuclear energy sector has also gained favor from international organizations like Intergovernmental Panel on Climate Change (IPCC) as an important energy option to attain the "zero emissions". However, there have been accidents like the Fukushima nuclear incident in Japan that have changed the political 
environment and perceptions towards nuclear energy. The commitment to mitigating greenhouse gas (GHG) was revised in Japan as a response. Although Japan committed to a $25 \%$ reduction in emissions from 1990 levels by 2020 , it only decreased by $3.8 \%$ from 2005 levels, translating to a 3.1\% increase in GHG from 1990 levels [35]. However, the nuclear reactors in Japan also restarted their operations since 2015 despite the lack of public acceptance.

An increase in global nuclear power production of about $80 \%$ is required by 2040 to achieve the sustainability target in which $85 \%$ of the global electricity needs to come from clean sources by 2040 compared with the existing $36 \%$. The use of nuclear power has reduced carbon dioxide $\left(\mathrm{CO}_{2}\right)$ emissions by over 60 gigatons, which is equivalent to two years' worth of global energy-related emissions [3]. Hence, it would be much harder to achieve a sustainable energy system without a proper nuclear investment. Furthermore, nuclear plants also help to keep the power grids stable by limiting the seasonal fluctuation impact from other renewables and reduce dependence on imported fuels, which has been prevalent in major ASEAN countries. However, public acceptance and trust needs to be garnered by informing the public about the importance of the energy source as a viable energy technology to address societal needs.

\subsection{Carbon Capture and Storage (CCS)}

Achieving long-term economic growth in the ASEAN will involve the continued use of fossil fuels. Increasing demand for coal is expected to cause a rise in emissions around $66 \%$ by 2040 [8]. How can the ASEAN region continue to use fossil fuels to accelerate economic growth without hurting the environment? CCS offers a viable pathway to use cheaper energy sources such as fossil fuels while minimizing their environmental impacts, as the technology can prevent around $90 \%$ of $\mathrm{CO}_{2}$ from entering the atmosphere by capturing the emissions produced from fossil-based electricity generation and uses. CCS technology also enables producing clean hydrogen from fossil fuels as the emitted carbon gets captured and geologically stored. Almost all of the world's hydrogen is sourced from gas, coal and the production of clean hydrogen using CCS technology and can be more cost-effective than producing clean hydrogen from renewables using electrolytes [7]. If combined with renewable biomass, CCS allows carbon dioxide to be taken out of the atmosphere and is carbon-negative.

Southeast Asia provides good opportunities for harnessing the CCS technology as the region has plentiful geological storage resources. Countries like Indonesia, Vietnam, Philippines and Thailand have 54 gigatons of storage capacity [36], which reflects that the region has sufficient capacity to conceal carbon dioxide. However, countries in the ASEAN region are developing CCS at different speeds. For instance, CCS technologies have gained much attention in Singapore across both the public and private sectors since 2017. Indonesia is also considering the development of large gas projects with high $\mathrm{CO}_{2}$ concentrations, even though there is a need to further codify the CCS legal framework. Malaysia, on the other hand, is focusing on the CCS development in the power and oil/gas sectors by undertaking capacity development and storage assessments alongside running legal and regulatory workshops. The Asian Development Bank (ADB) has also been promoting carbon capture, utilization and storage (CCUS) in Asia since 2009 [37]. The economic analysis by Asian Development Bank (ADB) showed that natural gas processing and power plants are the best capture source, as it is the lowest-cost option for carbon capture and storage in Southeast Asia [38]. However, the development and deployment of CCS in the ASEAN region need to overcome significant challenges such as generating investments, attracting climate financing, regional and international collaboration as well as establishing regulatory frameworks for $\mathrm{CO}_{2}$ storage. An effective stakeholder engagement, especially through a smooth public dialogue could enhance carbon capture and storage development, which could increase the commercial viability. 


\subsection{Hydrogen Energy}

Hydrogen is the most abundant chemical element available in the atmosphere and can be a viable source to electrify homes, transport and industry. Hydrogen is being pursued as a potential form of clean energy given its wide usage in areas such as ammonia production, petrochemical and oil refining industries and many others. Currently, around $95 \%$ of hydrogen is produced from coal and gas, also called "grey hydrogen", and a small portion is produced with carbon capture, sequestration and storage (CCS), called "blue hydrogen". Less than $5 \%$ of total hydrogen production is produced from renewables, also known as "green hydrogen" [7]. Green hydrogen obtained through the electrolysis of water could be a non-polluting alternative for energy. Green hydrogen could be adopted in sectors such as transport, power generation, construction buildings and energy storage as it can make a remarkable contribution to clean energy transitions. Hydrogen has the characteristics of being light, storable and energy-dense, and no direct emissions of greenhouse gases makes its an important part of a clean and secure energy future. A study has found out that the electricity demand would reach $3600 \mathrm{TWh}$, surpassing the total annual electricity generation of the whole European Union if all the current hydrogen production is to be transformed from green sources [39].

Hydrogen fuel has huge potential to combat climate change by facilitating the transition to low-carbon energy sources despite their existing low share in the global energy consumption. An increase in scope for renewable energy and continuous decrease in the costs demanded for innovative green technologies of which storage facilities developed through hydrogen is likely. Furthermore, research has shown that blending of hydrogen with natural gas could provide a smooth transition from the current hydrocarbon-based economy to a hydrogen carbon economy [40]. In a long-term transition toward a clean and sustainable energy future, hydrogen provides a flexible option and a more distributed energy system that ensures a clean and sustainable hydrogen future [41]. The system brought about by a hydrogen economy could provide an easy transition towards a renewable-based future for many countries in ASEAN, which demands infrastructure and high energy demands.

The cost of hydrogen will also decline by over $50 \%$ by 2040 if adopted across all sectors, making it as competitive as the price of gasoline [42].The current cost of supplying renewable is about five times higher than gas, but the cost will come down with an investment in hydrogen supply chains. Green hydrogen will serve as a catalyst to address the integration challenges hindered for wind and solar as the world is shifting towards a green economy. By 2023, many hydrogen projects in Organisation for Economic Cooperation and Development (OECD) countries are expected to be launched which includes major pipelines for distribution to end-users and electrolyzers [43]. Island countries, especially in the ASEAN region, will benefit substantially as hydrogen will accelerate the storage as a clean energy carrier [7].

However, the ASEAN region has not yet included hydrogen in its policy agenda in many countries as an alternative fuel. Nevertheless, policy measures are likely to be addressed on emerging and alternative technologies, as hydrogen and energy storage by ASEAN Plan of Action for Energy Cooperation (APAEC) Phase 2 is under preparation for endorsement at ASEAN Ministers on Energy Meeting. The OECD's action plan to increase the share of hydrogen in the energy mix could indeed be fulfilled with the support from APAEC. The energy leaders in ASEAN could also develop a clear strategy on ways to promote hydrogen use in transportation and power sectors not limited to refining, fertilizer and petrochemical industries. Countries such as Singapore, Malaysia, Thailand, Indonesia and the Philippines could learn lessons from OECD countries, China and European community to guide the investment in research and development for hydrogen produced from both renewables and non-renewables.

Southeast Asian countries can learn from neighboring economies such as China, which has already accelerated hydrogen investment support to local industries whereby about US\$2 billion is being injected. Similarly, Japan has been promoting the global adoption of hydrogen for vehicles, power plants and other usages. Brunei in the ASEAN region has 
also taken a lead in the supply chain of hydrogen as it has supplied the liquefied hydrogen to Japan since 2019. However, more energy is consumed by the liquefied hydrogen as it needs a temperature of minus 253 degrees Celsius in order to transform the cooled gas into a liquid form [7].

Japan has been pioneering the renewable hydrogen economy in which the production of hydrogen through the reformatting process of renewable electricity such as solar and nuclear is likely to bring a breakthrough in decarbonizing emissions. Japan also became the first country in East Asia to adopt a basic hydrogen strategy, which will ensure that the production will reach cost parity with gasoline fuel and power generation in the long term. The society's willingness to pay is also a major factor despite the efforts by governments and private sectors to adopt hydrogen practices. South Korea is another country that has set a target for hydrogen usage with $10 \%$ of total energy consumption by 2030 and $30 \%$ by 2040 in order to power selected cities and towns [7]. The South Korean government has also made an announcement to create three hydrogen cities by 2022 where hydrogen will be used for major urban functions such as cooling, electricity, heating and transportation.

New research efforts are also underway with regards to investigating new methods for chemical-based liquid hydrogen carriers. A study [44] in 2013 introduced a methodology to quantitatively analyze the energy system by looking into the relationship of green car technology and greenhouse gas reduction in the regions of South Korea. The research suggested that technology such as decarbonization should be enhanced through the production of hydrogen to replace the existing fossil fuel sources in the foreseeable future. A recent study [7] also supports the promising future role of renewable hydrogen in energy transition to decarbonize ASEAN's emissions based on the examination of the potential scalability of renewable hydrogen production from curtailed electricity.

\section{Policy Recommendations}

The development and deployment of green technologies are viable and necessary in Southeast Asia to address the critical issues of climate change and adaptation in the context of increasing energy demands. The development and deployment of green energy technologies will improve environmental quality, human welfare and overall help developing economies to achieve sustainable development goals. ASEAN as a regional multinational organization has a pivotal role to play to not only fulfill its global commitments of the United Nations Climate Change Conference (COP 21) but also to facilitate cross-sectoral partnerships for sustainable economic development. This is important to achieving the ASEAN Community Vision 2025, which aims to sustain the momentum of regional integration [45].

There seems to be lack of adequate experience and expertise in some ASEAN member states such as Vietnam, Malaysia and Indonesia when it comes to the evaluation of risks of renewable energy investments, which has translated into lack of financial support and public capital immobility towards renewable energy investment. The cost of deploying renewable energy sector has been continuously falling, which has increased prospects for accelerated investment shifting away investor's choices from fossil fuels towards renewables. Green technologies such as hydropower, geothermal and hydrogen carbon have become substantially competitive. For instance, the costs of solar PV, concentrating solar, onshore wind and offshore wind have fallen respectively by $82 \%, 47 \%, 39 \%$ and $29 \%$ between 2010 and 2019 [46].

Around $56 \%$ of capacity additions for utility-scale renewable power achieved lower electricity costs in 2019 than the cheapest new coal plant. The annual potential savings were projected around $\$ 23$ billion if $500 \mathrm{GW}$ of existing coal were to be replaced by solar wind [47]. This global trend is an indication for the policymakers in ASEAN also to emphasize alternative green energy options and exploit the huge benefits they bring. Technologies to reduce emissions from the power sector such as carbon capture, utilization and storage are essential, and efficiency must be achieved in sectors such as vast cooling and road transport. The gasification of biomass and solar-thermal technology create 
alternatives in producing hydrogen from renewable energy sources. Similarly, the surplus wind electricity is also used for hydrogen production as a means for storing energy, which reduces the risk from the curtailment of solar and wind power [7].

\subsection{Transitioning towards Hydrogen Carbon Economy}

The ASEAN countries could emphasize on an efficient interplay between energy, environment and economy in moving towards a hydrogen carbon economy. Hydrogen has major implications in various sectors such as transport. Countries like India have welcomed foreign investment in fuel cell vehicles and hydrogen transportation infrastructure, which have already started in some pilot cities. Similarly, in Japan, the Tokyo Metropolitan government has increased the number of hydrogen buses to 100 in 2020 [48]. As for the ASEAN region, the Sarawak Local Government in Malaysia is starting to operate hydrogen buses soon. Singapore is also collaborating with companies from Japan to explore the development of hydrogen as a new clean fuel to decarbonize emissions.

Hydrogen production mostly comes from natural gas as it consists of 70 million tones, which is around three quarters of the annual global or $6 \%$ of natural gas use. Coal also contributes equally, as countries like China have a major stake while only some of thei production of hydrogen comes from oil and electricity [40]. It can be observed from Figure 4 below that the support investments for hydrogen technologies have increased recently in many countries with around 50 targets, mandates and several policy incentives especially focused on the transport sector. Hydrogen production mostly comes from natural gas, as it consists of 70 million tonnes, which is around three quarters of the annual global or $6 \%$ of natural gas use.

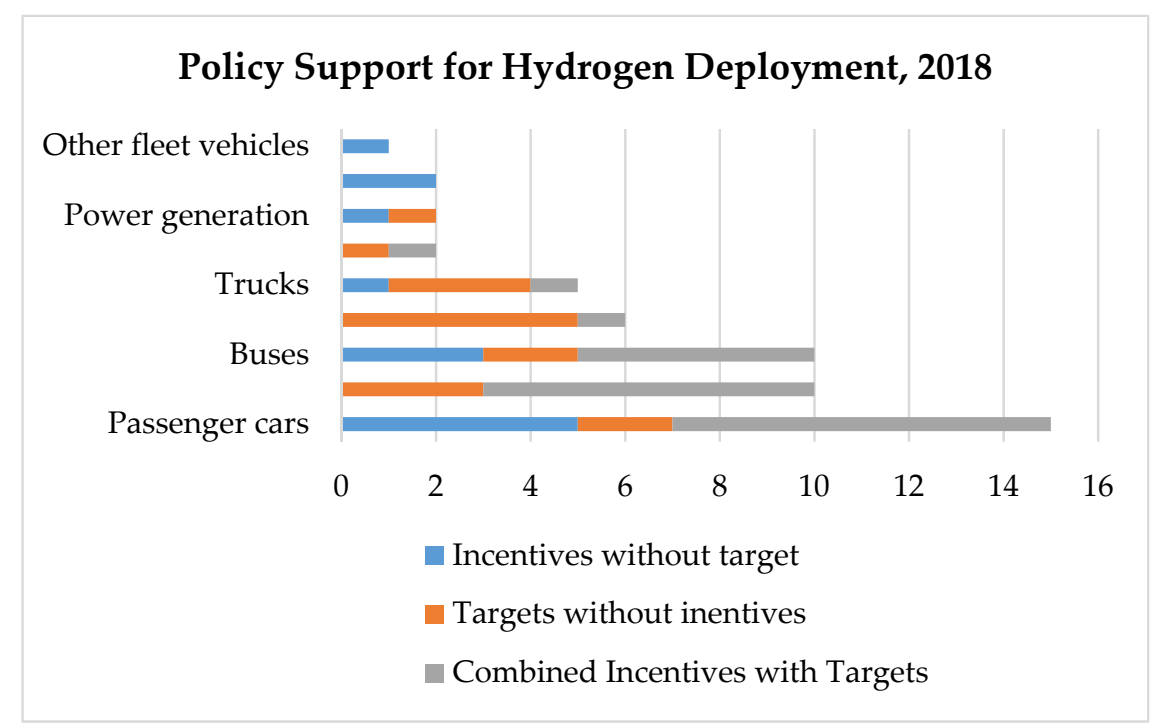

Figure 4. Support policies for hydrogen development. Source: [40].

There is not a one-size-fits-all solution when it comes to hydrogen policy. The production of both "blue" and "green" hydrogen include several opportunities and risks to the countries following the respective approaches, even though there are options available to deploy hydrogen products from both fossil fuels and low-carbon sources such as renewable electricity. On one hand, hydrogen based on fossil fuels may enable rapid scale-up in short term. However, there are minimal environmental benefits, and it requires carbon capture in the long term. On the other hand, the substantial application of hydrogen in big sectors such as transport and chemicals can bring efficiency to the energy system. This could bring numerous opportunities to exploit energy resources that are currently underutilized. The ASEAN government should align their ambition and approach for the use of hydrogen by considering the international practices as well as the market scope where it can be widely applied. 
There still remains a considerable gap towards realizing its potential despite the wide spectrum of opportunities entailed by hydrogen with its industry application. An actionoriented plan and vision is required both for the near future to make hydrogen feasible for that future as the support for clean energy transition is growing among policymakers in the ASEAN. An intelligible policy is essential to meet the long-term hydrogen goals as there are various risks associated in investments, which could be detrimental to many stakeholders given the complexity of hydrogen value chains. A standard regulation is required across the ASEAN countries to mitigate uncertainties and co-ordination problems. The IEA has stated four key value chains as an opportunity in the coming decade to accelerate the speed of hydrogen deployment focusing on different regions of the world. The ASEAN is focused as part of the fourth value chain as a part of Asia Pacific, along with Middle East, North Africa and Europe, which are "the first shipping routes", in order to kick-start international hydrogen trade for the ultimate global low-carbon market [49].

Hydrogen can be directly produced from increasingly demanded coal in the ASEAN with near-zero greenhouse gas emissions as carbon capture and storage technology becomes available. However, the development and deployment of certain green technologies like the carbon capture, utilization and storage requires appropriate institutional and policy set up as a prerequisite. There are raw materials widely used in infrastructure such as in construction, aerospace and automotive sectors, whereby traditional materials are replaced by carbon-based materials such as carbon composites and manufactured graphite. These materials can largely absorb the enormous amount of carbon products as countries like Canada, Japan and the US have already constructed and developed bridges with such mechanisms. One major advantage of carbon-composites in comparison to traditional materials such as steel is that it does not erode and is five times stronger than the mainstream heavy construction equipment [33]. There could be a significant decrease in $\mathrm{CO}_{2}$ emissions, which in turn would discontinue the cement-manufacturing plants by replacing concrete with carbon materials. There has been good progress made in terms of using carbon-based products as additives for substituting cements.

\subsection{Adapting Green Energy Financing for Green Deployment}

Finance is the engine of development of renewable energy projects, and financing of investments that provide environmental benefits through new financial instruments such as green bonds, green banks, carbon market instruments, fiscal policy, green central banking, fintech, community-based green funds is necessary to achieve the SDGs [50]. The ASEAN and the Southeast Asia governments should adopt these targeted funding channels, also known as green energy financing, for the greater deployment of green technologies in the region. A geographical mismatch between resource endowments and demand centers provides incentive for regional integration of power grids in order to bridge the gap but requires capital-intensive investments in physical interconnectors. Therefore, the hindrance of renewable energy development does not only include technological capacity but also access to finance in the ASEAN [51]. It is difficult for policymakers in determining the ways to make the transition towards a green economy from the existing coal generation in the absence of financing access, when generally, financial institutions show more interest in fossil fuel projects rather than in green projects. The cross-sector policy framework can enable integrative financing and development of renewable energy fostering energy efficiency and replacement of fossil fuels.

The Southeast Asian region has played a significant role under the agenda of "one community for sustainable energy" with publicly financed initiatives such as ASEAN Power Grid (APG) interconnection, Trans-ASEAN Natural Gas Pipeline (TAGP), energy efficiency, renewables, and regional level policy and planning [15]. All these initiatives require costly investments in capital expenditures and are risky which the private sector is not willing to bear and therefore requires appropriate public financing as evidenced. The breakthroughs in technology in the renewable sector can provide a resilient model forward on a low-carbon energy system by easing access to finance and overcoming financial 
barriers in the deployment of renewable energy. The stronger regional framework on green projects financing can serve as an extensive development plan and ensure a sustainable energy transition roadmap moving forward. Both regional coordination and cooperation with a strong political will from all the countries in the region will be vital for an integrated financial framework development in supporting infrastructure projects in the ASEAN.

The belt and road initiative introduced by China also has some major implications to the South East Asian economies such as promoting infrastructure projects through Chinese government financing in the region that relates with water resources and transboundary rivers. However, several positive and negative impacts may arise, creating political issues on the social and environmental front through these publicly financed projects [52]. Therefore, concerns can be raised while deploying green technology projects, especially when international collaborations take place. A regional governing institution focused on energy and use of market-based instruments can provide a platform for strengthening energy dialogues and facilitating the mobilization of green technologies to boost the energy infrastructure by attracting financing. Furthermore, the role of the private sector is also equally important and will not only ensure civic engagement but also support the leveraging of public funds. The policymakers around ASEAN have been increasingly trying hard to ensure reliable and affordable sustainable energy solutions. It is equally important to focus on efficiency while developing investment infrastructure for fuel and power supply.

Commitment for funding from both public and private sectors is crucial. For example, many public sources have played important roles in financing thermal power plant projects and large-scale renewables such as hydropower, while most wind and solar PV projects have relied on private finance supported by policy incentives. Civic engagement and initiatives from investors and companies also play an equally vital role. A finding of the South Korean government showed how government aid and other public finance is deployed. Figure 5 shows the amount of public and private investments in the ASEAN power generation by different sources. Public investments are dominant in the region, with significant involvement in electricity generation from coal and gas. The challenge for policymakers is to entice more private investments into the renewable power sector in the ASEAN.

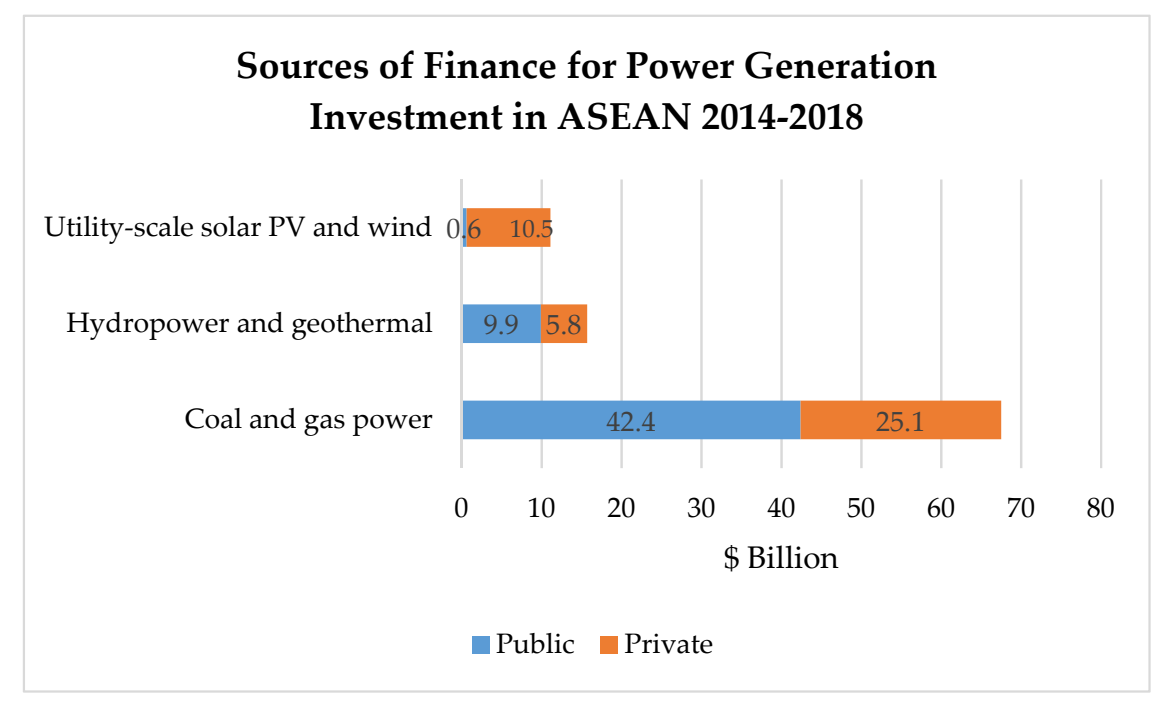

Figure 5. Financing sources. Source: Adapted from IEA [8].

Figure 5 above also indicates that more investments should be channeled towards sustainable energy, and the deployment of renewables should be scaled up although notable progress has been made towards disincentivizing the consumption of fossil fuel. Figure 6 below shows the share of financial instruments on total renewable energy investments in the ASEAN between 2009-2016. Loan and concessional loans remain the two most popular 
financing instruments, which highlights the need to increase the access to credits for the development and deployment of green energy in the ASEAN.

\section{Renewable Energy Investments by Type of Financial Instrument in ASEAN, 2009-2016}

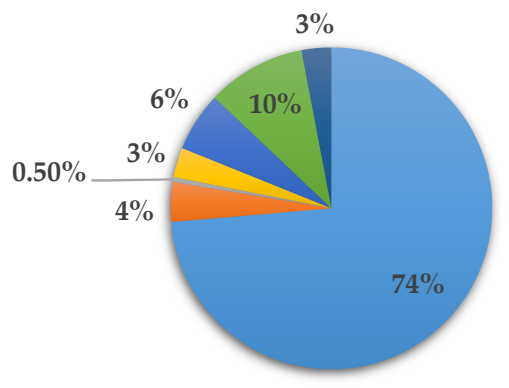

\section{Loan}

Equity

\section{Guarantee}

Credit line
Grant

Concessional loan

- Partial Credit Guarantee

Figure 6. Renewable energy investments Type. Source: Adapted from IRENA [53].

\subsection{Managing Energy, Environmental and Financial Risks}

Green projects are associated with risks pertaining to being new technologies and their relatively lower rate of return. The rapid rise of energy demand in Southeast Asia is poised to bring several risks to the region from an energy financing perspective. The region is forecasted by IEA to register a net deficit in energy trade of $\$ 300$ billion per year due to increasing imports of oil by 2040 [3]. The government budget will likely remain tightened as the increase in subsidies for renewable energy continues while also distorting the market-based energy prices. Setting energy prices based on market signals by reducing fossil fuel consumption subsidies will attract more sustainable energy consumption and investments in the ASEAN. While the progress is notable in eliminating fossil-fuel subsidies; the process still remains incomplete. The current dependence on the import of oil is $65 \%$ and is expected to rise to $80 \%$ in 2040, and it therefore remains a serious energy security concern for the region [18]. The high-carbon-intensive power sector in Southeast Asia, especially due to the rise in coal demand, is expected to amplify environmental risks through increased $\mathrm{CO}_{2}$ emissions to almost 2.4 gigatons by 2040 [18]. This will negatively impact the environmental quality, adding to already existing poor urban air quality and congested transportation infrastructure.

The governments of ASEAN need to address the energy security risks by taking into account the financial, environmental and social viability of the projects. To achieve this, various frameworks could be developed in the process of procurement and contracting mechanisms in the renewable sector. The support to the financial system and enhancement of sustainability utilities could also strengthen the market. The challenge of limited infrastructure particularly in the Philippines and Indonesia, which are archipelagic in nature, has obstructed effective renewable energy deployment as they have fragmented electricity transmission grids. Similarly, the lack of regulatory frameworks on green technology development and deployment brings major challenges too. Countries like Brunei do not have a specific policy framework in place to regulate the development of renewable energy, although it has been reported to be in progress [54]. There was major infrastructure devastation in Laos PDR due to a lack of coordination, creating human risk as the failure of an auxiliary dam washed out 13 villages, affecting around 11,000 people [55]. The high-risk 
nature of hydropower dam construction should not be underestimated despite the huge potentials for hydropower with an unrealized power potential of $22.3 \mathrm{GW}$ in the region.

Vietnam is another major player in the hydropower sector and has an estimated 16.68GW capacity, but the lessons from Laos have allowed the country to focus on less intrusive sources of renewable energy. The revised master plan of Vietnam has not focused on the development of large-scale hydropower as a renewable source of energy but promotes increasing the capacity to $21.6 \mathrm{GW}$ in 2020 , which is approximately $27.8 \mathrm{GW}$ by 2030 with small and multipurpose projects [56]. Vietnam has a heavy reliance on coal-fired power, as in 2020 alone, the country's capacity stood at $49.3 \%$. The coal's share in Vietnam is expected to reach $53.2 \%$ by 2030 as the development project is demanding more energy despite the efforts by the government's revised master plan to reduce reliance on coal. Given the cheaper cost associated with renewables and wind and solar, sources from coal could be shifted and reduce the current import of coal, which is around 30 million tones in Vietnam [57].

The proper coordination among the government agencies and the private sector is crucial towards prioritizing renewable energy policies into implementation. Awareness among the public about the benefits of using green technologies can boost energy efficiency as well environmental conservation initiatives. Multilateral power trading agreements will be crucial along with the expansion of cross-border transmission, which can lower the building and operating costs of ASEAN region's power systems. Countries such as Lao PDR export $67 \%$ of electricity generated from hydropower, which is almost $30 \%$ of all its total exports, with main buyers being in ASEAN countries itself such as Thailand, Vietnam and Cambodia [53]. The regional integration could facilitate the growing demand for energy by deploying green technologies such as wind and solar PV and most importantly the application of hydrogen carbon-based instruments.

\section{Conclusions}

The purpose of this study was to formulate the scenario-based policy lessons and framework in the case of ASEAN economies in facilitating the development and deployment of green technologies and alternative energy options. In doing so, the study reviewed the literature around green energy deployment in the context of green growth and energy transition and discussed the current status of renewable energy development in the ASEAN. Alternative energy options such as nuclear and hydrogen energy prospects were discussed, while the study proposed hydrogen fuel as a way forward in meeting the energy and environmental objectives in the ASEAN. Some of the underlying research questions that this study aimed to shed light on and expose as urgent areas of future research include: (i) Why is the deployment of renewable energy low in the ASEAN, and what frameworks are needed to better support their wider deployment of green technologies like wind and solar in Southeast Asia in the context of energy transition? (ii) What are the policy and institutional frameworks required to implement innovative green technologies such as carbon capture, utilization and storage in the region as demand for fossil fuels, in particular, coal escalates? (iii) What is the scope for energy efficiency improvements in the region within the context of the push towards greener technology development and deployment? (iv) How can cross-sectoral partnerships between the governments, businesses, and NGOs in the ASEAN help to mitigate the threats of climate change collectively? However, it was beyond the scope and not the aim of this paper to comprehensively provide answers to each of these individual questions.

The study concludes that carbon capture, utilization and storage (CCUS) will be a vital technology in the ASEAN to reduce emissions from the power sector and from industry while allowing the use of fossil fuels to achieve economic growth. The study proposes that transitioning to a hydrogen carbon economy, adapting to green energy finance for development and managing financial risks in promoting green energy development are necessary and urgent in the ASEAN region to adapt to climate change. The decreasing costs for renewable electricity, especially from solar PV and wind, seems to support the 
production of electrolytic hydrogen, making it a low-cost supply technology option for hydrogen. Similarly, the increasing pressure from international agreements such as COP21 will demand countries to deploy alternative fuel pathways in their energy mix.

The International Monetary Fund forecasted the global economy to grow negatively at $4.9 \%$ in 2020, which will demand that policymakers come up with major economic stimulus packages to combat the COVID-19 crisis [58]. Investment in clean energy with technological solutions will not only be an ideal option from an environmental standpoint but will also fulfil the unemployment gap by creating green-technology-related jobs while spurring economic growth and is perceived to be vital in emerging regions like ASEAN. In addition, the falling costs of renewables can also provide policymakers a perspective to revisit the energy policy planning documents and have a long-term vision about green technology deployment. Batteries, hydrogen and carbon capture are viable technologies as they have the potential to be deployed in mass scale, which could help in achieving global clean energy transition. According to a recent analysis done by IEA, governments are believed to be driving 70\% of global energy investments [59]. A proper coordination and leadership from the ASEAN governments to engage multiple stakeholders is important to achieve climate change goals with the appropriate deployment of green technologies. A coordinated energy strategy in the ASEAN will also improve the nuclear prospects, which are complicated by political factors, and public acceptance towards nuclear energy needs to be boosted.

Implementing energy efficiency improvements policy in the ASEAN through policy measures such as attracting Foreign Direct Investment (FDI) and reducing energy consumption in public goods provisions such as streetlights are desirable [60]. Cross-sectoral partnership and international power connectivity in the ASEAN region should be the way forward. The European Union provides a perfect example, whereby their partnership in renewable energy lowered the energy supply from coal by 3\% [8]. We propose that short-term and medium-term policies to facilitate decarbonization include boosting public acceptance to nuclear energy, implementing energy efficiency improvement policies and complete elimination of fossil fuel consumption subsidies. The longer-term policies are to deploy CCS technologies as an enabler of hydrogen energy and to increase both the public and private sector energy investments in and development of CCS technologies. These are important policy lessons for the ASEAN governments to accommodate in energy policy crafting and promote sustainable development in the region through green energy development and deployment as a viable strategy to adapt to climate change.

Author Contributions: R.N.-conceptualization, methodology, writing-original draft preparation, writing-review and editing, validation, formal analysis, investigation; H.P.-writing-review and editing, resources, project adminstartion, funding acquisition; A.K.-writing-original draft preparation. All authors have read and agreed to the published version of the manuscript.

Funding: This research paper was carried out under the funding from the Economic Research Institute for ASEAN and East Asia.

Acknowledgments: We also acknowledge the valuable comments received from Fukunari Kimura, Jun Arima and participants at the First Working Group Meeting-Energy Sustainability and Climate Change in ASEAN-held on 14 September 2020. The authors are also grateful to the academic editor and the three anonoymous reviewers for providing helpful comments in improving the paper. All remaining errors are the sole responsibility of the authors alone.

Conflicts of Interest: The authors declare no conflict of interest.

\section{References}

1. Steffen, W.; Richardson, K.; Rockström, J.; Cornell, S.E.; Fetzer, I.; Bennett, E.M.; Sörlin, S. Planetary boundaries: Guiding human development on a changing planet. Science 2015, 347. [CrossRef]

2. Raitzer, D.A.; Bosello, F.; Tavoni, M.; Orecchia, C.; Marangoni, G.; Nuella Samson, J.G. Southeast Asia and The Economics of Global Climate Stabilization; ADB: Metro Manila, Philipphines, 2015; pp. 1-191.

3. IEA. Southeast Asia Energy Outlook; IEA: Paris, France, 2019; pp. 1-18. [CrossRef] 
4. IRENA. REmap-Renewable Energy Outlook for ASEAN; International Renewable Energy Agency (IRENA): Abu Dhabi, UAE, 2016.

5. Rooney, K.; Writer, S.; Content, F. Can Southeast Asia Keep up with Growing Energy Demand? 2020, pp. 4-7. Available online: https://www.weforum.org/agenda/2019/12/asean-southeast-asia-energy-emissions-renewables/ (accessed on 20 August 2020).

6. International Resources Group. USAID Asia-Pacific Regional Climate Change Adaptation Assessment. Options. 2010. Available online: https:/ / pdf.usaid.gov/pdf_docs/PNADS197.pdf (accessed on 10 July 2020).

7. Phoumin, H.; Kimura, F.; Arima, J. Potential Renewable Hydrogen from Curtailed Electricity to Decarbonize ASEAN's Emissions: Policy Implications. Sustainability 2020, 12, 560. [CrossRef]

8. IEA. Nuclear Power in a Clean Energy System; IEA: Paris, France, 2019. [CrossRef]

9. Louis, J. Rising Temperatures Surge Energy Demand in ASEAN. The ASEAN Post. 1-4 March 2020. Available online: https: / / theaseanpost.com/article/rising-temperatures-surge-energy-demand-asean (accessed on 10 July 2020).

10. Erdiwansyah, R.M.; Sani, M.S.M.; Sudhakar, K. Renewable energy in Southeast Asia: Policies and recommendations. Sci. Total Environ. 2019, 670, 1095-1102. [CrossRef]

11. Singh, A.; Jamasb, T.; Nepal, R.; Toman, M. Electricity cooperation in South Asia: Barriers to cross-border trade. Energy Policy 2018, 120, 741-748. [CrossRef]

12. Halawa, E.; Geoffrey, J.; Shi, X.; Novieta, H.S.; Rabindra, N. The Prospect for an Australian-Asian Power Grid: A Critical Appraisal. Energies 2018, 11, 200. [CrossRef]

13. Nepal, R.; Jamasb, T. Caught between Theory and Practice: Government, Market and Regualtory Failure in Electricity Sector Reforms. Econ. Anal. Policy 2015, 46, 16-24. [CrossRef]

14. Schmidt, T.S.; Huenteler, J. Anticipating industry localization effects of clean technology deployment policies in developing countries. Glob. Environ. Chang. 2016, 38, 8-20. [CrossRef]

15. Shi, X.; Malik, C. Assessment of ASEAN Energy Cooperation within the ASEAN Economic Community. In ERIA Discussion Paper Series; 2013; Available online: https:/ / www.eria.org/ERIA-DP-2013-37.pdf (accessed on 10 July 2020).

16. Taguibao, J.G. Sustainable Energy Policy in Southeast Asia: Domestic Variation and Congruence in Policy Discourses. Asian Politics Policy 2019, 11, 327-346. [CrossRef]

17. Li, B.; Nian, V.; Shi, X.; Li, H.; Boey, A. Perspectives of energy transitions in East and Southeast Asia. Wiley Interdiscip. Rev. Energy Environ. 2020, 9, 1-7. [CrossRef]

18. Lee, H.H.; Iraqui, O.; Wang, C. The Impact of Future Fuel Consumption on Regional Air Quality in Southeast Asia. Sci. Rep. 2019, 9, 1-20. [CrossRef] [PubMed]

19. Taghizadeh-Hesary, F.; Rasoulinezhad, E. Analyzing Energy Transition Patterns in Asia: Evidence from Countries with Different Income Levels. Front. Energy Res. 2020, 8, 1-13. [CrossRef]

20. Rehbein, J.A.; Watson, J.E.M.; Lane, J.L.; Sonter, L.J.; Venter, O.; Atkinson, S.C.; Allan, J.R. Renewable energy development threatens many globally important biodiversity areas. Glob. Chang. Biol. 2020, 26, 3040-3051. [CrossRef] [PubMed]

21. Trueman, C. How Are Countries in Southeast Asia Embrcing Green Technology. 2018. Available online: https:/ / www.cio.com/ article/3322530/how-are-countries-in-southeast-asia-embracing-green-technology.html (accessed on 10 July 2020).

22. ASEAN Secretariat. ASEAN Sustainable Urbanisation Strategy. In Global Environmental Issues, 2nd ed.; ASEAN: Jakarta, Indonesia, 2012. [CrossRef]

23. IRENA. Renewable Capacity Highlights Renewable Generation Capacity by Energy Source. March 2018. Available online: http:/ / www.irena.org/- / media/Files/IRENA/Agency/Publication/2018/Mar/RE_capacity_highlights_2018.pdf?la=en\& hash=21795787DA9BB41A32D2FF3A9C0702C43857B39C (accessed on 10 September 2020).

24. Salleh, S.F.; Roslan, M.E.M.; Shamsuddin, A.H.; Tuan Abdullah, T.A.B.; Sovacool, B.J. Transitioning to a Sustainable Development Framework for Bioenergy in MALAYSIA: Policy Suggestions to Catalyse the Utilisation of Palm Oil Mill Residues. Energy Sustain. Soc. 2020, 10. [CrossRef]

25. Tun, M.M.; Juchelkova, D.; Win, M.M.; Thu, A.M.; Puchor, T. Biomass Energy: An Overview of Biomass Sources, Energy Potential, and Management in Southeast Asian Countries. Resources 2019, 8, 81. [CrossRef]

26. Kurniawan, R. Indonesia to Have Its First and Largest Floating Solar Power by 2019-2021. 2020. Available online: https:/ /www. rambuenergy.com/2017/12/indonesia-to-have-its-first-and-largest-floating-solar-power-by-2019/ (accessed on 20 August 2020).

27. Hajramurni, A. Jokowi Inaugurates First Indonesian Wind Farm in Sulawesi. Jkt. Post. 2018. Available online: https:// www.thejakartapost.com/news/2018/07/02/jokowi-inaugurates-first-indonesian-wind-farm-in-sulawesi.html (accessed on 10 July 2020).

28. Clean Cooking Alliance Philippines. 2020, pp. 1-2. Available online: https://www.cleancookingalliance.org/country-profiles/61 -philippines.html (accessed on 10 July 2020).

29. IEA. The Future of Cooling in Southeast Asia-Analysis-IEA. 2018, pp. 1-3. Available online: https://www.iea.org/reports/thefuture-of-cooling-in-southeast-asia (accessed on 20 August 2020).

30. IRENA. Global Renewables Outlook: Energy transformation 2050. In International Renewable Energy Agency; Available online: https:/ / www.irena.org/publications/2020/Apr/Global-Renewables-Outlook-2020 (accessed on 20 November 2020).

31. Nian, V.; Chou, S.K. The state of nuclear power two years after Fukushima-The ASEAN perspective. Appl. Energy 2014, 136, 838-848. [CrossRef]

32. Nian, V.; Hari, M.P. Incentivizing the Adoption of Nuclear and Renewable Energy in Southeast Asia. Energy Procedia 2017, 105, 3683-3689. [CrossRef] 
33. Zink, J.C. Trend favors nuclear-hydrogen economy. Power Eng. 2003, 107, 20.

34. Brown, L.C.; Besenbruch, G.E.; Lentsch, R.D.; Schultz, K.R.; Funk, J.F.; Pickard, P.S.; Showalter, S.K. High efficiency generation of hydrogen fuels using nuclear power. Gen. At. 2003, 29-30. [CrossRef]

35. Thornhill, B.J.; Roston, E. Persistent Carbon Emissions Signal Global Climate Goal Is Out of Reach. 2019-2021. 2019. Available online: https: / / www.bnnbloomberg.ca/persistent-carbon-emissions-signal-global-climate-goal-is-out-of-reach-1.1357053 (accessed on 10 July 2020).

36. Zhang, T. CCS Development in Southeast Asia, Global CCS Isntitute. May 2020. Available online: https://www.globalccsinstitute. com/wp-content/uploads/2020/05/Brief_CCS-Development-in-South-East-Asia_May-2020.pdf (accessed on 20 August 2020).

37. ADB. Asia Wakes Up to CCUS, ADB Knowledge Events. 2019. Available online: https://events.development.asia/learningevents/asia-wakes-ccus (accessed on 10 July 2020).

38. ADB. Prospects for Carbon Capture and Storage in Southeast Asia. 2013. Available online: http://hdl.handle.net/11540/1434 (accessed on 10 July 2020).

39. Evwind. Hydrogen from Wind Energy and Solar Power, the Future. 2020, pp. 1-8. Available online: https://www.evwind.es/2020/0 1/21/hydrogen-from-wind-energy-and-solar-power-the-future/73170 (accessed on 10 July 2020).

40. Muradov, N.Z.; Veziroğlu, T.N. From hydrocarbon to hydrogen-carbon to hydrogen economy. Int. J. Hydrog. Energy 2005, 30, 225-237. [CrossRef]

41. Barreto, L.; Makihira, A.; Riahi, K. The hydrogen economy in the 21st century: A sustainable development scenario. Int. J. Hydrog. Energy 2003, 28, 267-284. [CrossRef]

42. Jose, M.B.; Hasegawa, T. The Future of Hydrogen for G20. Seizing today's opportunities. In Report Prepared by the IEA on Hydrogen; 2019. Available online: https:/ /www.iea.org/reports/the-future-of-hydrogen (accessed on 10 July 2020).

43. IEA. Deploying Renewables in Southeast Asia-Trends and Potentials; IEA: Paris, France, 2010; pp. 1-164. [CrossRef]

44. Lee, D.H.; Park, S.Y.; Hong, J.C.; Choi, S.J.; Kim, J.W. Analysis of the energy and environmental effects of green car deployment by an integrating energy system model with a forecasting model. Appl. Energy 2013, 103, 306-316. [CrossRef]

45. ASEAN. Asean Community Vision 2025. 2015, p. 8. Available online: http://www.asean.org/wp-content/uploads/images/20 15/November/aec-page/ASEAN-Community-Vision-2025.pdf (accessed on 10 July 2020).

46. IRENA. How Falling Costs Make Renewables a Cost-Effective Investment. 2020, pp. 1-8. Available online: https://www.irena. org/newsroom/articles/2020/Jun/How-Falling-Costs-Make-Renewables-a-Cost-effective-Investment (accessed on 30 September 2020).

47. Creamer, T. Replacing World's Costliest $500 \mathrm{GW}$ of Coal with Solar and Wind Would Shave \$23bn off System Costs. 2018, pp. 1-10. Available online: https://www.engineeringnews.co.za/article/replacing-worlds-costliest-500-gw-of-coal-withsolar-and-wind-would-shave-23bn-off-system-costs-2020-06-02/rep_id:4136\#: \{\}:text=Replacingthecostliest500GW,2019\%2 Canewreportshows (accessed on 10 July 2020).

48. Deloitte China. Fueling the Future of Mobility Hydrogen and fuel cell solutions for transportation. Financ. Advis. $2019,1,1$.

49. Bermudez, J.M.; Hasegawa, T. Hydrogen. IEA. 3-4 June 2020. Available online: https://www.iea.org/reports/hydrogen (accessed on 30 September 2020).

50. Sachs, J.D.; Woo, W.T.; Yoshino, N.; Taghizadeh-Hesary, F. Importance of Green Finance for Achieving Sustainable Development Goals and Energy Security. In Handbook of Green Finance. Sustainable Development; Sachs, J., Woo, W., Yoshino, N., TaghizadehHesary, F., Eds.; Springer: Singapore, 2019. [CrossRef]

51. Shi, X. The future of ASEAN energy mix: A SWOT analysis. Renew. Sustain. Energy Rev. 2016, 53, 672-680. [CrossRef]

52. Williams, J.M. Emerging costs of China's belt and road strategy for transboundary water in south and southeast Asia. Int. J. Energy Water Resour. 2019, 3, 81-92. [CrossRef]

53. IRENA. Renewable Energy Market Analysis: Southeast Asia; International Renewable Energy Agency: Abu Dhabi, UAE, 2018; Available online: www.irena.org (accessed on 25 October 2020).

54. Asean, T.; Team, P. ASEAN's Renewable Energy Challenges. 2020, pp. 1-5. Available online: https://theaseanpost.com/article/ aseans-renewable-energy-challenges (accessed on 25 October 2020).

55. Gnanasagaran, A. Lao Dam Failure Creates Hydroelectric Woes. (August 2018). 2020, pp. 1-6. Available online: https:/ / theaseanpost. $\mathrm{com} /$ article/lao-dam-failure-creates-hydroelectric-woes (accessed on 10 June 2020).

56. Greening, P.; Joyce, M.; Strachan, E. Energy in ASEAN: Renewable Energy in Vietnam. 2020, pp. 1-15. Available online: https: / / www.lexology.com/library / detail.aspx?g=4e781400-114f-4181-a647-f6c5aa222c7d (accessed on 10 July 2020).

57. Vu, K.; Gloystein, H. In Vietnam's Booming Energy Sector Coal Reigns, but Renewables Play Catch-Up. Reuters. 2019. Available online: https:/ / www.reuters.com/article/us-vietnam-energy-analysis/in-vietnams-booming-energy-sector-coal-reignsbut-renewables-play-catch-up-idUSKCN1SU0KJ (accessed on 20 August 2020).

58. IMF. World Economic Outlook Update. IMF 2019, 2, 6.

59. Birol, F.; IEA. How to Make the Economic Recovery from Coronavirus an Environmentally Sustainable One. IEA Commentary, Prospect Magazine. 2020. Available online: https:/ / www.iea.org/commentaries/how-to-make-the-economic-recovery-fromcoronavirus-an-environmentally-sustainable-one (accessed on 10 August 2020).

60. Nepal, R. Overcoming the Challenge of Energy Efficiency Financing in Asia. Asia Pathways-The Blog of the Asian Development Bank Institute. 20 November 2020. Available online: https:/ / www.asiapathways-adbi.org/2020/11/overcoming-challenge-energyefficiency-financing-asia/ (accessed on 20 August 2020). 